\title{
EVALUATING THE EFFECTS OF BEACH NOURISHMENT ON LITTORAL MORPHODYNAMICS AT KUALA NERUS, TERENGGANU (MALAYSIA)
}

\author{
EFFI HELMY ARIFFIN*1,2, MUHAMMAD SYAKIR ZUFAYRI ZULFAKAR ${ }^{2}$, NURUL \\ SHAHIDA REDZUAN ${ }^{1}$, MANOJ JOSEPH MATHEW $^{3}$, MOHD FADZIL AKHIR ${ }^{2}$, NOR \\ BAKHIAH BAHARIM ${ }^{1}$, NOR ASLINDA AWANG ${ }^{4}$ AND NOR AIENI MOKHTAR ${ }^{5}$
}

\begin{abstract}
${ }^{1}$ Faculty of Marine and Science Environment, ${ }^{2}$ Institute of Oceanography and Environment, ${ }^{5}$ Faculty of Ocean Engineering Technology and Informatics, Universiti Malaysia Terengganu, 21030 Kuala Nerus, Terengganu, Malaysia. ${ }^{3}$ Shale Gas Research Group Institute of Hydrocarbon Recovery, Universiti Teknologi Petronas, 32610 Seri Iskandar, Perak. ${ }^{4}$ Coastal Management \& Oceanography Research Centre, National Hydraulic Research Institute of Malaysia (NAHRIM), Ministry of Natural Resources \& Environment, Lot 5377, Jalan Putra Permai, 43300 Seri Kembangan, Selangor
\end{abstract}

*Corresponding author: effihelmy@umt.edu.my

Submitted final draft: 14 November 2019 Accepted: 21 December $2019 \quad$ http://doi.org/10.46754/jssm.2020.07.005

\begin{abstract}
Since 2008, Kuala Nerus has undergone rapid urbanization along its coastline, resulting in the loss of sand along the littoral zone. Due to the heavy erosion in 2012 at Tok Jembal beach that migrated to Universiti Malaysia Terengganu (UMT) beach in 2013, the Department of Irrigation and Drainage has implemented a coastal defence project to mitigate erosion by building a series of ripraps/revetments along the coasts. Additionally, breakwaters and groyne structures were built in combination with beach nourishment programme. For the sustenance of the local fishermen community, the Malaysia Public Works Department replaced one of the breakwaters to a jetty-type breakwater at Tok Jembal beach. Shoreline evaluations, beach profile measurements and numerical modelling were used in this present study to identify the effectiveness of combining the coastal defence and beach nourishment programmes. The combination of programmes successfully initiated the accretion of a $\sim 30 \mathrm{~m}$ beach dune and created new beaches. However, erosion remains persistent in the beach that was unprotected and exposed directly to the South China Sea. We posit that a combination of coastal defence and beach nourishment programmes can potentially interrupt dynamic coastal processes, especially the current parameters.
\end{abstract}

Keywords: Beach dune, coastal processes, coastal defence, numerical modelling, monsoon.

\section{Introduction}

The Beaches are in a constant state of erosion, accretion and recovery in response to waves, currents, winds, storms and sea-level change (Muehe, 2003; Frihy et al., 2004; Ariffin et al., 2016; 2018a; 2018b). Active developments along poorly managed shorelines can potentially lead to property loss (Peterson \& Bishop, 2005; Ashraful Islam et al., 2016; Ariffin, et al., 2018b; 2019). A guideline prepared by the Department of Irrigation and Drainage, Malaysia, emphasises two methods by which shorelines can be protected: i) curative measure and ii) proper measure. The curative measure includes performing erosion control works on critical areas. Normally, in the curative measure, the concerned authorities will build the riprap and revetment. The approach, however, has been reported to shift erosion to adjacent unprotected beaches.

In the Bengal beach, India, the parts to the south of the southern groyne showed predominant sediment deposition, resulting in a wide beach, while, the beach to the north of the northern groyne is exposed to erosion, leading to a narrow beach (Mohanty et al., 2012). Similarly, in most of the beaches in Taiwan, erosion is observed at one site and accretion at another. However, this occurrence is closely related to sediment source from many of the Taiwan Rivers, in that, shoreline recovery depends on available sediment flux. Often, sediment deficiency is the main concern that contributes to coastal erosion (Hsu et al., 2007). Sediment deficiency can be 
overcome by sustainable development planning and optimising the usage of coastlines.

Beach nourishment programme is one example of sustainable development planning. This programme has been applied globally in tackling the main issue of coastal erosion, i.e., sediment deficiency. Beaches in countries such as the United States of America (Peterson \& Bishop, 2005), Turkey (Türker \& Kabdaşli, 2007), Brazil (Muehe, 2003), and India (Pandian et al., 2004) are protected with this nourishment programme. The programme proved to successfully prevent further erosion and provide new recreational sandy stretches.

However, beach nourishment programmes will not be able to function independently. Therefore, for a significant impact, the construction of breakwaters and/or groynes are needed to support and work along with the beach nourishment programme (Frihy et al., 2004) and incorporation of hard structures such as breakwaters need to take into account the impact of the structures to the coastline. If not, the combined approach can be a failure. Therefore, comprehensive studies to identify any impact of the hard structures on respective coastlines have to be carried out before implementing the combined programme. In India, Vaidya et al. (2015) studied a series of breakwater and groyne impacts to the shoreline before any coastal planning had taken place. While in Thailand, Saengsupavanich (2013) and Prukpitikul et al. (2018) made proper plans to use the breakwaters to reduce wave height before it moved to the coastline.

In Malaysia, beach nourishment has been introduced in Penang, Negeri Sembilan and Kelantan (refer Figure 1 for the location). In Negeri Sembilan, specifically in Port Dickson, a popular picnic destination in the west coast of Peninsular Malaysia, beach nourishment programme has proven to be a successful. Contrarily, at Pantai Sabak, Kelantan, the programme seems to be insignificant in protecting the beach's backshore due to strong northeast monsoon storms. The tempests were responsible for the loss of nearly half of a newly constructed beach berm structure in 2004 (Nor Hisham, 2006). This situation is best explained by the fact that the northeast monsoon storms in the east coast of Peninsular Malaysia are significantly stronger compared to the southwest monsoon storms in the west coast of Peninsular Malaysia (Nor Hisham, 2006; Ariffin, et al., 2018a; 2018b; 2019; Yaacob et al., 2018).

In recent years, the expansion of understanding and knowledge on beach protection methods and techniques, especially on the initiative to combine coastal defence structures and beach nourishment, has shown successful results in protecting shorelines of coastal towns such as in Dungun, Terengganu (Nor Hisham, 2006). In this case study on the Kuala Nerus coast, shoreline changes, beach profile measurements, particle size and hydrodynamic data allow a comparative analysis on the effect of beach nourishment on littoral morphodynamics.

A combination of multi-methods in relation to seasonal monsoon can serve as a preliminary guideline to reduce erosion through the construction of breakwaters and beach nourishment projects. Furthermore, this study can also fill the gap in available literature on monsoon dominated coasts, especially in Southeast Asia. Furthermore, this case study can serve as an appropriate preliminary guideline to reduce erosion through the construction of breakwaters and beach nourishment projects, especially in monsoon environments.

\section{Methodology}

\section{Study Area}

A $3 \mathrm{~km}$ coastal strip, stretching from Tok Jembal to Universiti Malaysia Terengganu (UMT) beaches in Kuala Nerus provenance was chosen as the study area (Figure 1) due to its highgradient beaches (Ariffin, et al., 2018b; 2019). Since 2010, after the extension of the airport runway at Tok Jembal beach, there was vast number of documented erosional events that have taken place along this strip (Ariffin et al., 2016; 2018b). Sediment deficiency problems 
in Tok Jembal had called for the construction of many series of ripraps/revetments to prevent further erosion (Ariffin et al., 2016; 2018a; 2018b).

Unfortunately, the ripraps/revetments at Tok Jembal had caused the erosion to move northward, towards the UMT beach. According to Ariffin et al. (2018b), based on the failure of the previous mitigation plan, the Department of Irrigation and Drainage (Malaysia) carried out beach nourishment programme with a combination of breakwaters and groyne. The combination resulted in the formation of sand tombolo that slowly accreted behind the breakwater (breakwater 2 and 3 ) in front of the UMT beach (Figure 1). This present study was intentionally carried out at the UMT beach due to the intensified coastal dynamics, especially on the beach profile changes and increased current speed. Three transects were chosen on the beach to carry out this study. Transects were named Transect 1 (T1), Transect 2 (T2) and Transect 3 (T3) and are highlighted in the red box in Figure 1.

The study area is geographically set within an estuarine located backshore. It also consists of an artificial and natural lagoon at Tok Jembal and UMT, respectively. The artificial lagoon at Tok Jembal was constructed on demand by the local fishermen community that wanted a protected lagoon to park their small boats, especially during the monsoon storm season. UMT lagoon is a habitat of many species of mangrove plants such as the Rhizophora sp., Avicennia sp. and Nypa sp. The sediments of the UMT shore is predominantly characterised by coarse sand (Ariffin, et al., 2018a). Littoral drift of sediments from the Terengganu River towards the Tok Jembal and UMT coastline must be the source of this sandy sediment (Ariffin et al., 2016).

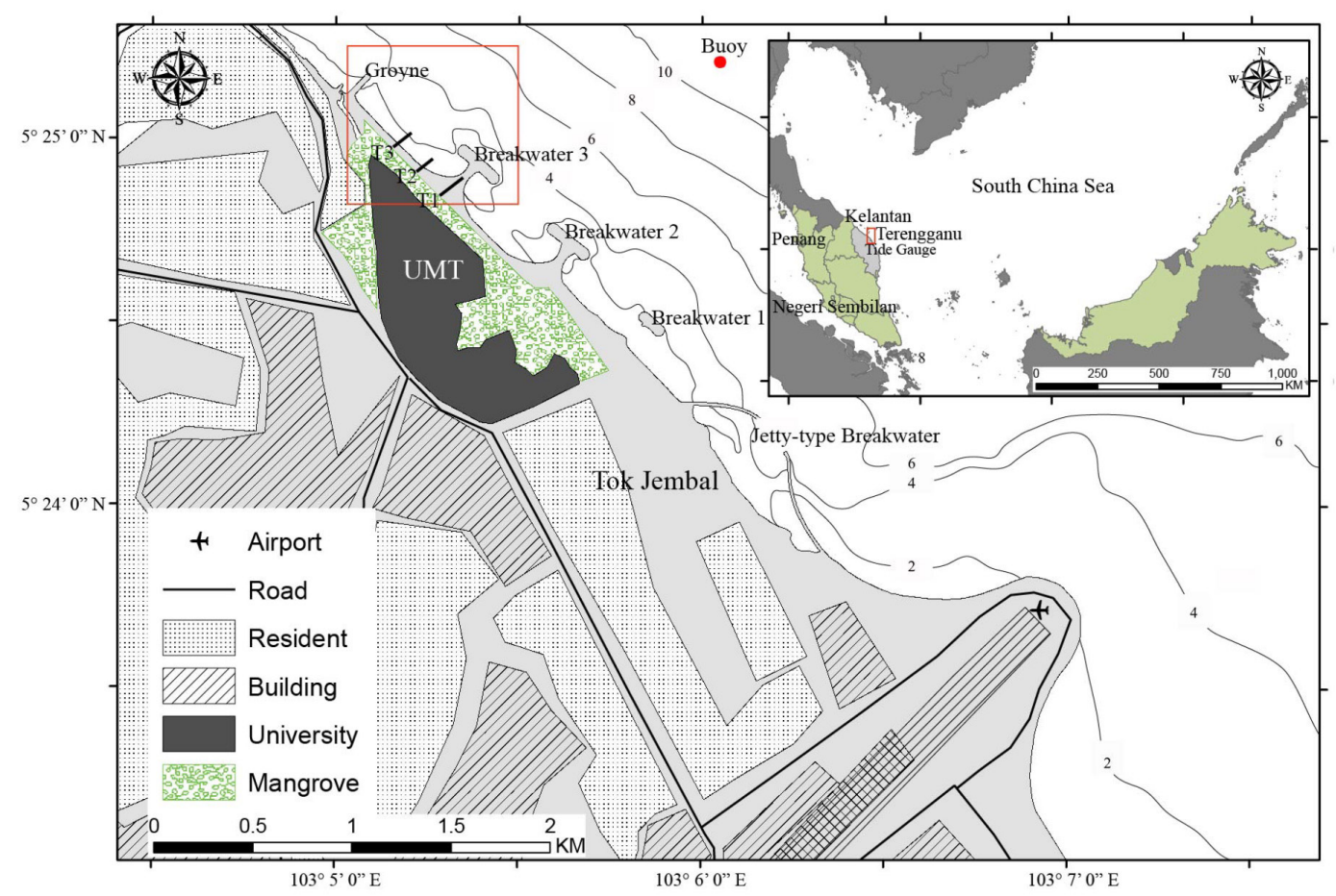

Figure 1: Study site that covers the area from Tok Jembal to Universiti Malaysia Terengganu (UMT) beaches in Kuala Nerus provenance. The red box indicates the location of Transect 1 (T1), 2 (T2) and 3 (T3) for beach profiling. 
Kuala Nerus coast is influenced by two main monsoon wind regimes, the southwest and the northeast monsoons. These two distinct wind directions were determined by the means of wind modelling recorded between $2000-2013$ (Kok et al., 2015). In the period of the southwest monsoon, the winds blow south-westerly over the
South China Sea between May and September and during the northeast monsoon, the winds blow north-easterly between November and March. The wind rose distribution in 2013 \& 2017 illustrates the environmental condition in this study (Figure 2a), while Figures $2 b$ and $2 c$ reveal the wave rose and tide, respectively.

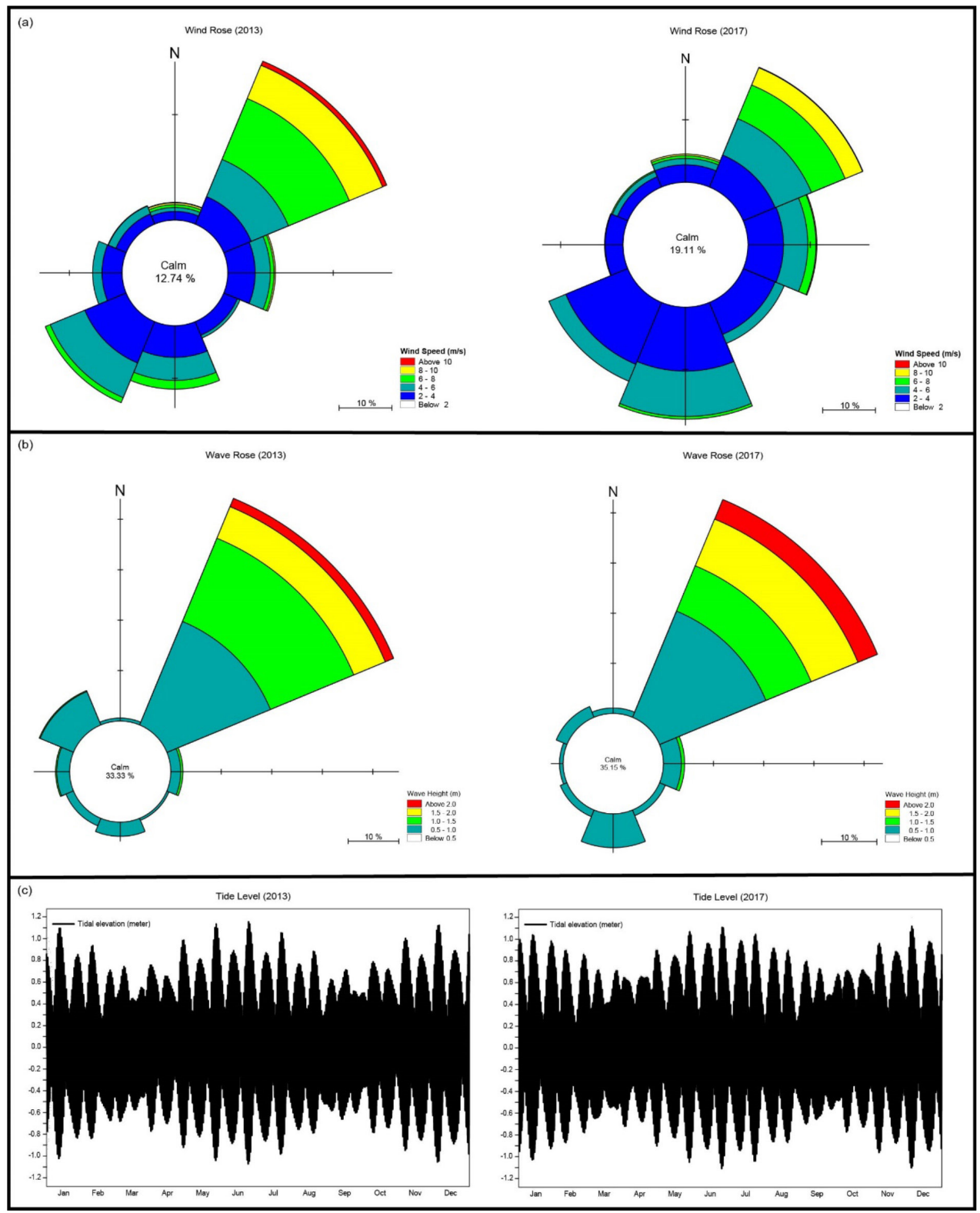

Figure 2: The condition of environmental parameters in this study, a) wind rose; b) wave rose and; c) tide level 
Considering the effect of beach nourishment on littoral morphodynamics, investigation of shoreline change was carried out along the 3 $\mathrm{km}$ stretch of the Kuala Nerus coastline. In detail, beach profile along with beach volume was analysed to determine the efficiency of the beach nourishment programme. To identify the variation of the current parameters (speed and direction), numerical modelling was simulated to compare the before and after effects of the programme.

\section{Shoreline Changes}

A Digital Shoreline Analysis System (DSAS) software developed by Thieler et al. (2009) was used to compare the shoreline changes between the years 2013-2017. Aerial photographs were extracted from an Unmanned Aerial Vehicle (UAV) - Drone Mavic. The photographs were processed with aid from geometric correction using UTM 48 - WGS 1984 projection. For a more precise result, the Ground Control Point (GCP) of aerial photographs were set to any recognised and identified landmarks (i.e., buildings) using Real-Time Kinematic (RTK). By referring to decrement or addition of vegetation lines, 200 transects with a $20 \mathrm{~m}$ interval were generated with data incorporating only the End Point Rate (EPR) method.

The EPR was selected as it was the most suitable method for this study after taking into account only four years of shoreline evolution. The evolution was divided into short periods of distance on the shoreline movement by the time elapsed between the earliest and latest measurements (i.e., the oldest (2013) and the most recent (2017) shoreline). For a clearer perspective, we compared the aerial photographs acquired between 2013 and 2017. EPR data showed negative and positive values which indicated erosion and accretion rates, respectively.

\section{Beach Profile Measurements}

Shoreline changes were measured by carrying out beach profile measurements along with beach volume. The measurements were obtained using the Profiler 3.2 XL program (Cohen, 2016). To compare the beach profile between monsoons, surveys were carried out in July 2013 (southwest monsoon), December 2013 and December 2017. The survey in July 2017 was referred to as the base of beach profile (first profile). In December 2013 the survey was without the beach nourishment programme and but in December 2017 it was after the programme. The beach profiles were measured from the beach dune (vegetation area) to the low tide mark using total station instruments (Topcon GPT-3100N) on the three selected transects (T1, T2 and T3) in this study (Fig. 1). The readings were adjusted to the DTGSM datum level.

\section{Numerical Model}

Estimation of the current parameters along the coast in December 2013 (without beach nourishment programme) and December 2017 (after beach nourishment programme) were modelled with Mike-3 module - Flow Model (DHI, 2011). The modelling process consisted of a mesh grid in the range of $4.8-6^{\circ} \mathrm{N}$ to $102-$ $104^{\circ} \mathrm{E}$ in the Kuala Nerus area (Figure 3). Bathymetry was generated using CMap in DHI Mike to simulate the numerical model.

However, the water level forcing the three open boundaries, i.e., boundary 2 (south), boundary 3 (east) and boundary 4 (north) were specified based on global tide model prediction that was computed in Mike-21 (Fatimah \& Nuramalina, 2012; Awang et al., 2014). The current model was forced by a series of wind data extracted from the European Centre for Medium-Range Weather Forecasts (ECMWF, 2017) that are located offshore.

Model calibration was performed to tune the model to an acceptable tolerance result by using water surface elevation parameter. The calibration was done using the value suggested by DHI (2011). The bias and root mean square error (RMSE) value between the measured current speed from the Acoustic Doppler Current Profiler (ADCP) (Fig. 1 shows the location of buoy for ADCP) and simulated output value were later calculated and compared as in Figure 


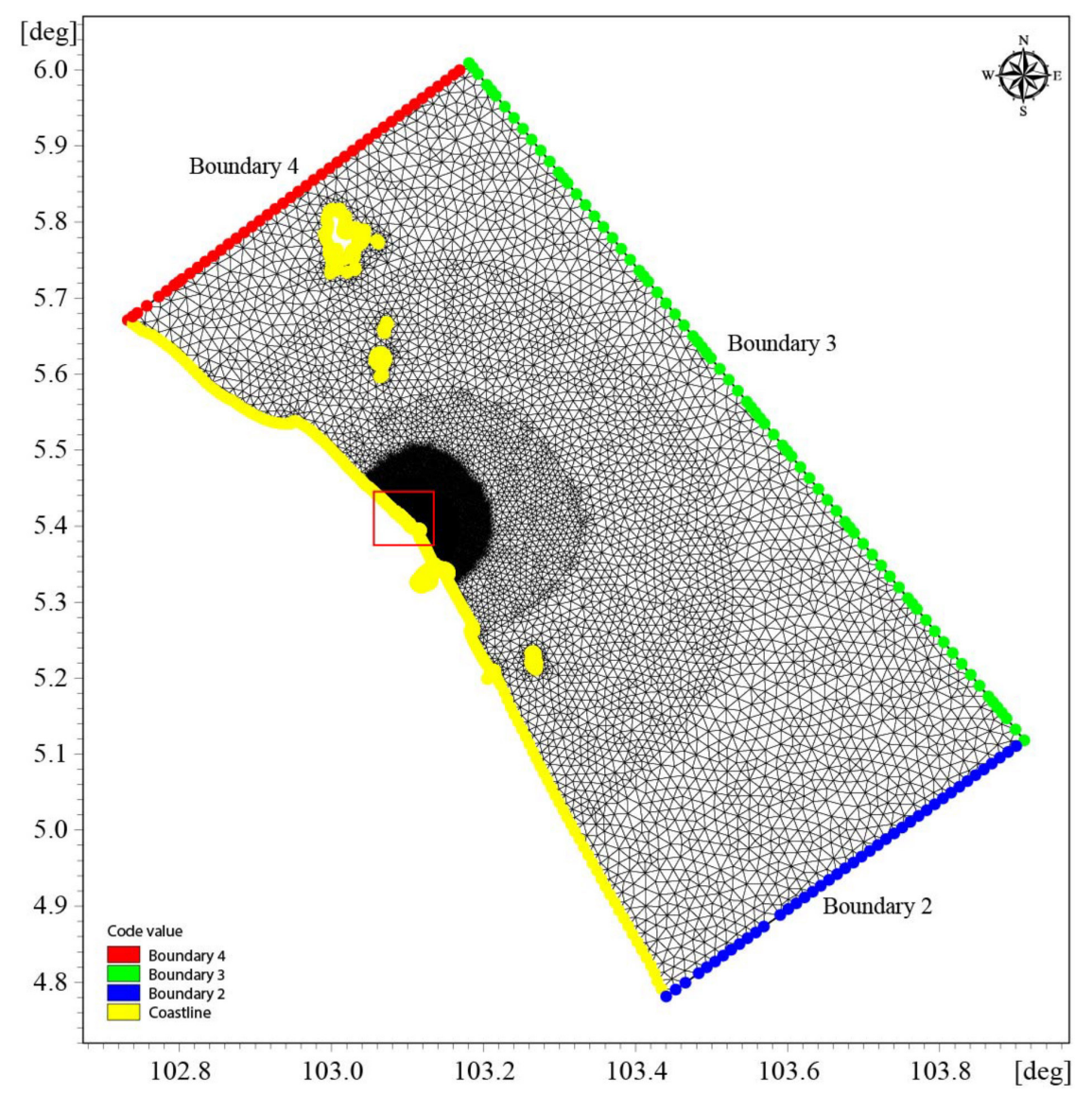

Figure 3: Mesh setup at Kuala Nerus coastline. Locations of the study area are enclosed in the red box

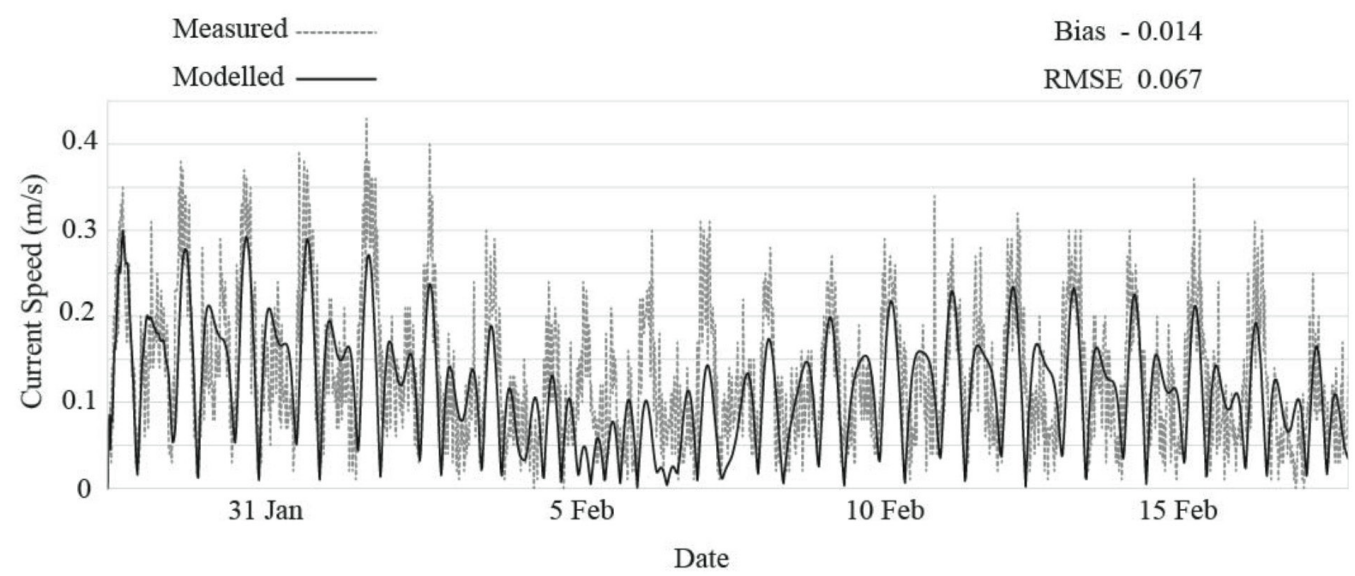

Figure 4: Validation for current speed measured from the Acoustic Doppler Current Profiler (ADCP) and model simulation at location of buoy 
4. The validation period started from 29 January until 15 February 2014.

The bias and RMSE values recorded were - $0.014 \mathrm{~m} / \mathrm{s}$ and 0.067 , respectively (Figure 2). These values are more precise than the values that were reported by Mirzaei et al. (2013) (bias: -0.10; RMSE: 0.44) and Daud \& Akhir (2015) (bias: 0.2; RMSE: 0.15 ) and this validates that the model setting was significant and can be simulated for further analysis.

\section{Results and Discussion}

The main findings of this study are discussed according to shoreline changes, beach profile and current parameters. The results from the current parameters, which included information on current speed and direction, can be linked with shoreline changes and beach profile data.

\section{Shoreline Changes}

According to Ariffin et al. (2018b), Kuala Nerus has been facing problems due to erosion since 2008, after the extension of the airport runway. The subsequent construction of a series of coastal defence worsened the erosion phenomenon. This problem compelled the Department of Irrigation and Drainage to initiate the beach nourishment programme with a series of breakwaters and groyne in this area. From 2013 to 2017, Tok Jembal shoreline showed a negative change at a maximum rate of $-20 \mathrm{~m}$ (Fig. 5). The area behind the jetty-type breakwater at Tok Jembal, however, displayed a positive $+8 \mathrm{~m}$ accretion. According to Saengsupavanich (2013), Aouiche et al. (2016) and Prukpitikul et al. (2018), the jetty-type breakwater (or detached breakwaters) is able to reduce storm-associated energy, such as strong currents and waves, which has resulted in sediment accretion behind the breakwater.

In contrast to the Tok Jembal coast, the UMT coast received several erosion and accretion events. The sand tombolo alone successfully promoted sand accretion in the range of +30 to $+40 \mathrm{~m}$. The groyne structure, which is as efficient as the sand tombolo, promoted approximately $+30 \mathrm{~m}$ sand accretion at the southern part of the UMT coast. It is believed that the structure plays a significant role in protecting the area from storms.

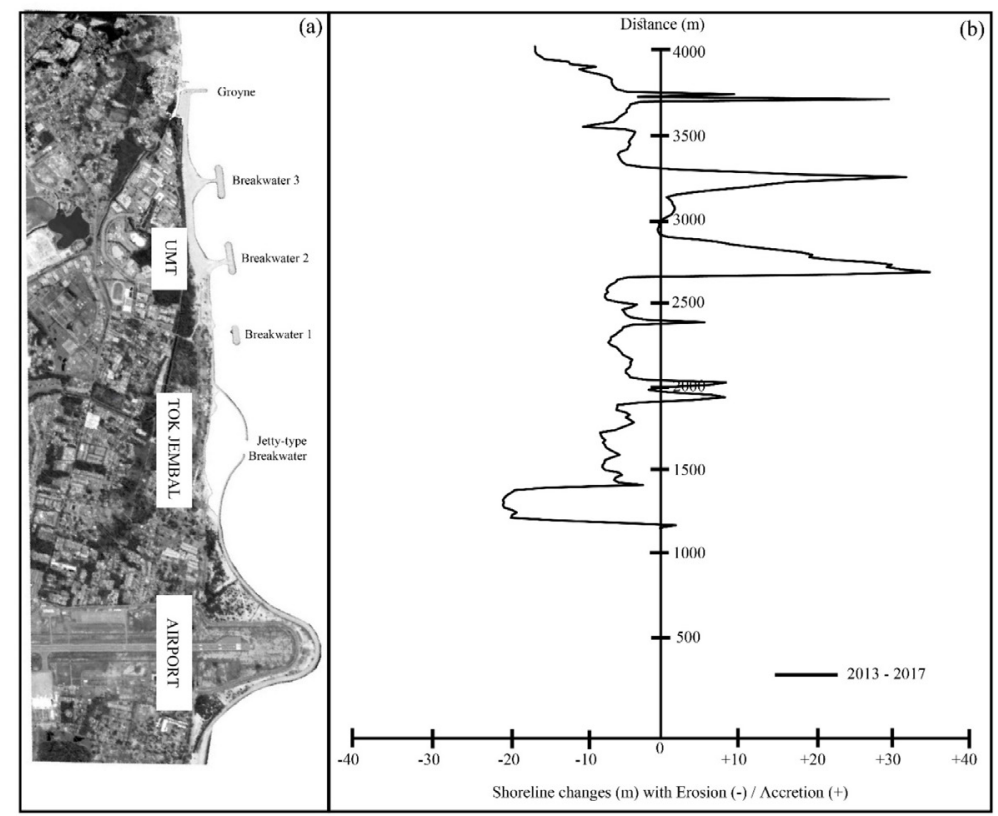

Figure 5: Shoreline changes between 2013 and 2017 with (a) the current shoreline in 2017 and (b) erosion and accretion rates 
Interestingly, there were events of sand erosion which took place; i.e., i) between the breakwater (breakwater 3) and groyne structure, and; ii) closer to the north part of the groyne at the UMT coast (Figure 5). Erosion displayed a maximum value of $-10 \mathrm{~m}$ and $-20 \mathrm{~m}$, respectively. According to Hsu et al. (2007) and Kaliraj et al. (2013), the groyne design with an extended structure towards the sea, potentially caused sediment accretion at only one side of the structure, while the adjacent side would demonstrate erosion. This proves that erosion only occurred at one site.

\section{Beach Profile}

After the erosional regime migrated to the UMT beach in 2013, a riprap was built by the UMT management in the same year (Figure 3) aimed to sustain and protect the beach dune during the storm season (December 2013). However, referring to the July 2013 data (base of beach profile), overall (T1, T2 and T3) beach profile in December 2013 showed erosion with a collapse of a significant area of the beach during the calm season (Ariffin, et al., 2018b).

Considering the assets of both UMT and residents at Tok Jembal area, the Department of Irrigation and Drainage implemented a beach nourishment programme with a series of breakwaters and a groyne starting in 2016 . However, increasing cost and longer budget approval time by the Malaysian Ministry of Finance disrupted the beach nourishment programme or project. While waiting for the budget to be approved, the erosion level had catastrophically continued to rise. Even after the approval of the budget, quite a large amount had to be allocated specifically to mitigate the latest mentioned erosion problem.

On the other hand, T1 and T2 displayed an accretion of $+13.919 \mathrm{~m}^{3}$ and $+19.044 \mathrm{~m}^{3}$ (Table 1), respectively. Moreover, the beach dune showed to have positively extended at $+30 \mathrm{~m}$ (Figures $6 \mathrm{a}$ and $6 \mathrm{~b}$ ). The sand dune at $\mathrm{T} 2$, however, was steeper as it faces the open South China Sea as compared to T1 that is protected by the breakwater. Normally, the beach will be creating a tombolo of sand behind the breakwater when the hydrodynamics in the area are slow (Peterson \& Bishop, 2005; Nor Hisham, 2006; Saengsupavanich, 2013; Prukpitikul et al., 2018). The sand tombolo was observed to establish with scattered vegetation which is seen at the beach dune.

Contrary to T1 and T2, T3 was actively eroded by the monsoon storms in December 2017 that caused its beach dune to lose a total of $15 \mathrm{~m}$ width and $8.343 \mathrm{~m}^{3}$ volume. This area is exposed to a more energetic disturbance (current flanked by groyne and breakwater) than at $\mathrm{T} 1$ and $\mathrm{T} 2$. The beach at $\mathrm{T} 3$ was significantly eroded in December 2013 before the breakwater was constructed by the government to protect the coastline. The ability of the breakwater to the wave diffraction process, consequently formed a new beach shape (Aouiche et al., 2016). Absence of vegetation on the beach dune at T3 further indicated that transect was actively disturbed. Therefore, the Department of Irrigation and Drainage built a new riprap in 2017 to protect the beach dune (Figure 6c).

\section{Current Parameter}

Numerous studies have reported that the airport runaway extension in 2010 has caused fuzziness in the hydrodynamic parameters, especially the water current at Tok Jembal coast (Mohd Radzi et al., 2014; Ariffin et al., 2016; 2018b; Ariffin, 2017). The problem intensified at the UMT coast in a northward direction in 2013 (Figure 7a). After the beach nourishment programme in combination with a series of breakwaters and groyne, the current parameter showed a significant positive change in 2017.

Jetty-type breakwater at Tok Jembal coast led to two different situations. Firstly, the inside of the breakwater displayed slow current speed. The slow current managed to create eddies in that enclosed area, which has high potential in restoring the shorelines (Pattiaratchi et al., 2009). Secondly, contrary to the inside, the breakwater causes an exceptionally high current speed outside of the jetty-type breakwater, moving northward and parallel to shorelines. 

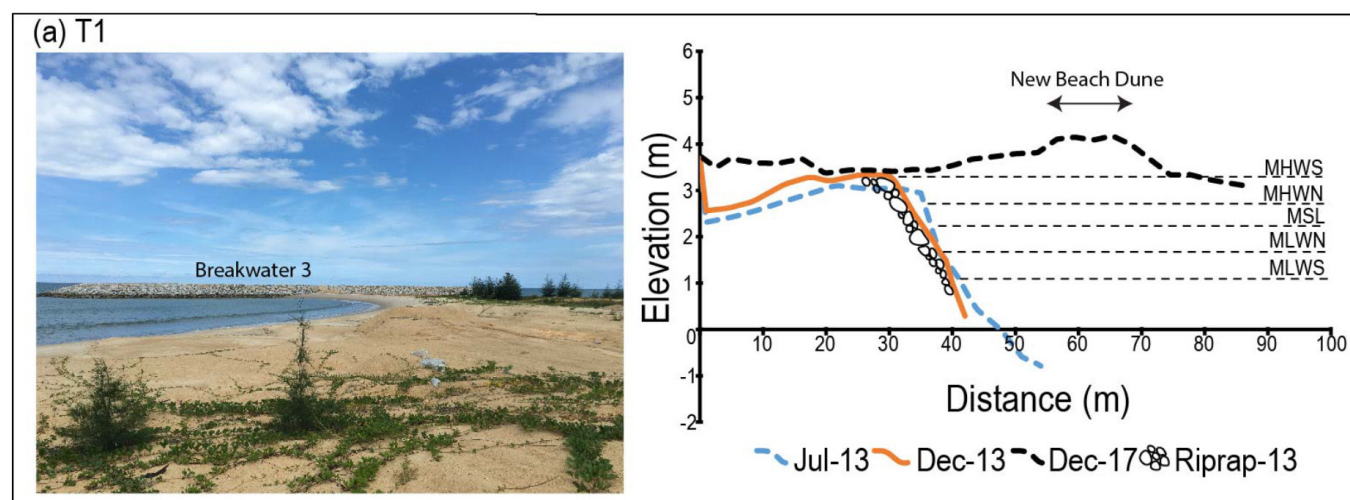

- Jul-13 Dec-13-・Dec-1788 Riprap-13
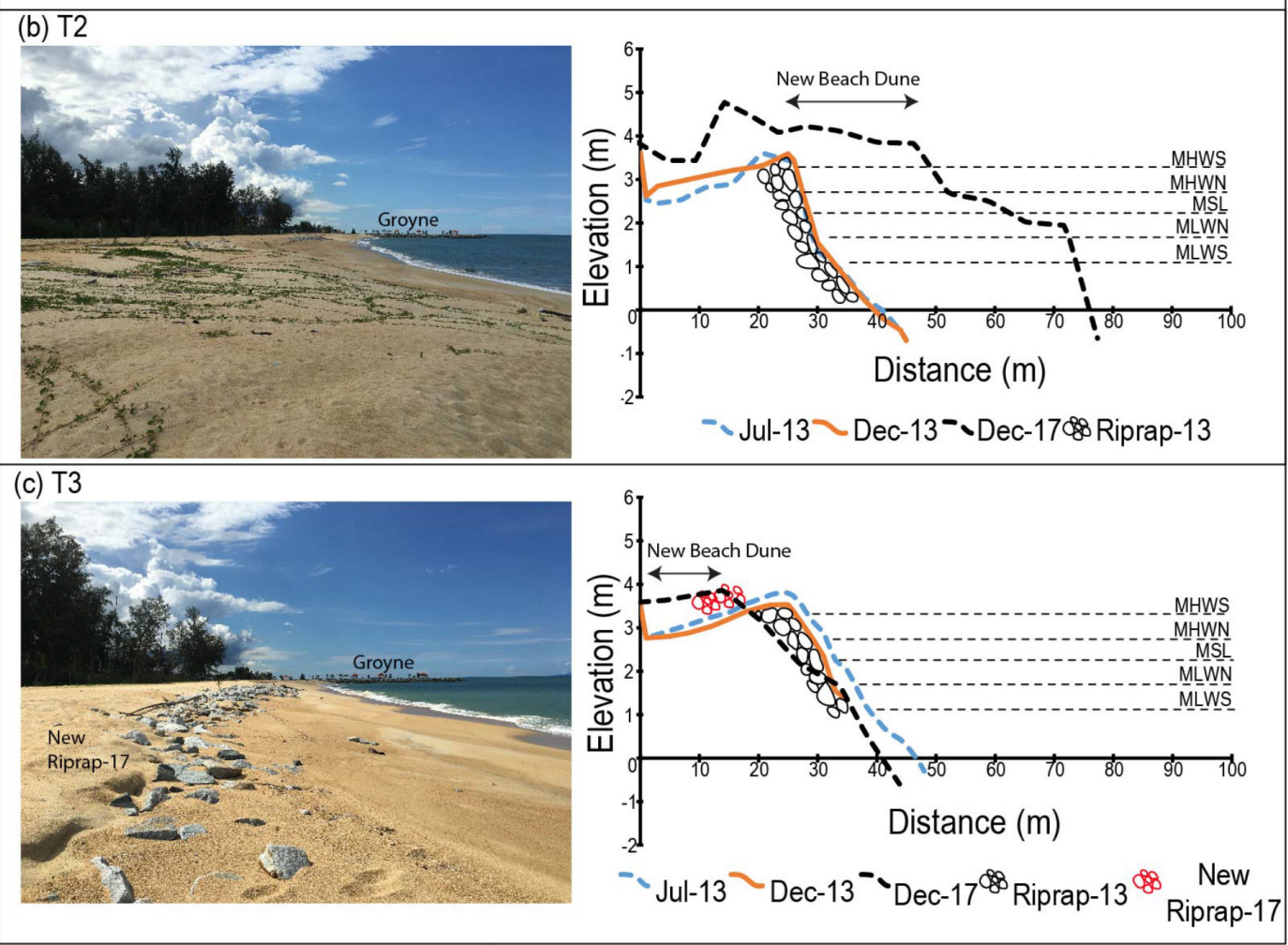

Figure 6: Beach profile sequences in comparison between 2013 and 2017 at Universiti Malaysia Terengganu beach (elevations are relative to DTGSM datum): (a) T1-Transect 1; (b) T2-Transect 2; and (c) T3-Transect 3

The high intensity current speed was actively moving towards the adjacent breakwater, which consequently caused the unsuccessful formation of sand tombolo at the breakwater 1 (Figure 7b).

At the UMT coast, eddies were observed between breakwater 2 and 3 and were in higher intensity compared to those formed inside the jetty-type breakwater at Tok Jembal coast. In the area between the breakwater 3 and the groyne, high intensity current speed had directly hit the coast and moved past the groyne (red box in Figure 7). Numerous studies have reported that groynes which reclamation cross to the sea caused high current intensity in other areas that are able to increase the erosion rate on the coast (Hsu et al., 2007; Pattiaratchi et al., 2009; Kaliraj et al., 2013). 
Table 1: Beach volume sequence for three transects at Universiti Malaysia Terengganu beach as July 2013 is base profile with comparison year profile of 2013 and 2017. The minus '-' value indicates the beach volume rate of sand eroded; plus '+' value indicates the beach volume rate of sand deposited (refer to Figure 3 for the 2-D graph).

\begin{tabular}{cccccc}
\hline & \multicolumn{2}{c}{$\mathbf{2 0 1 3}$} & $\mathbf{2 0 1 7}$ & \multicolumn{2}{c}{ Beach Volume Rate Changes } \\
\cline { 2 - 6 } Transect & \multicolumn{5}{c}{ Volume in cubic meter } \\
& July & December & December & (A) & (B) \\
\hline T1 & 150.084 & 151.613 & 164.003 & +1.529 & +13.919 \\
T2 & 155.362 & 156.718 & 174.406 & +1.356 & +19.044 \\
T3 & 158.275 & 153.311 & 149.932 & -4.964 & -8.343 \\
\hline
\end{tabular}

*A: Northeast Monsoon 2013 (from July 2013 to December 2013); B: Northeast Monsoon (from July 2013 to December 2017)

(a) 2013

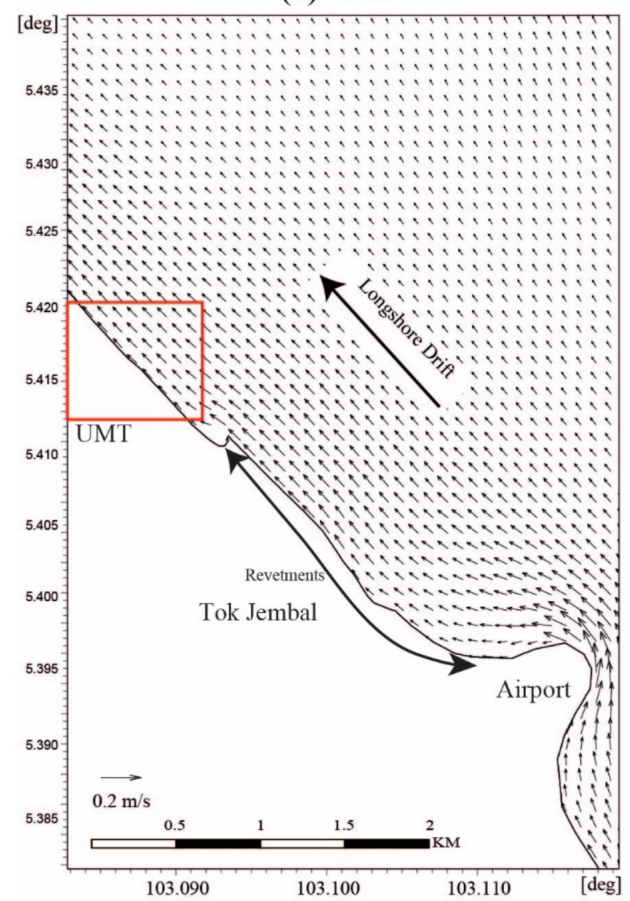

(b) 2017

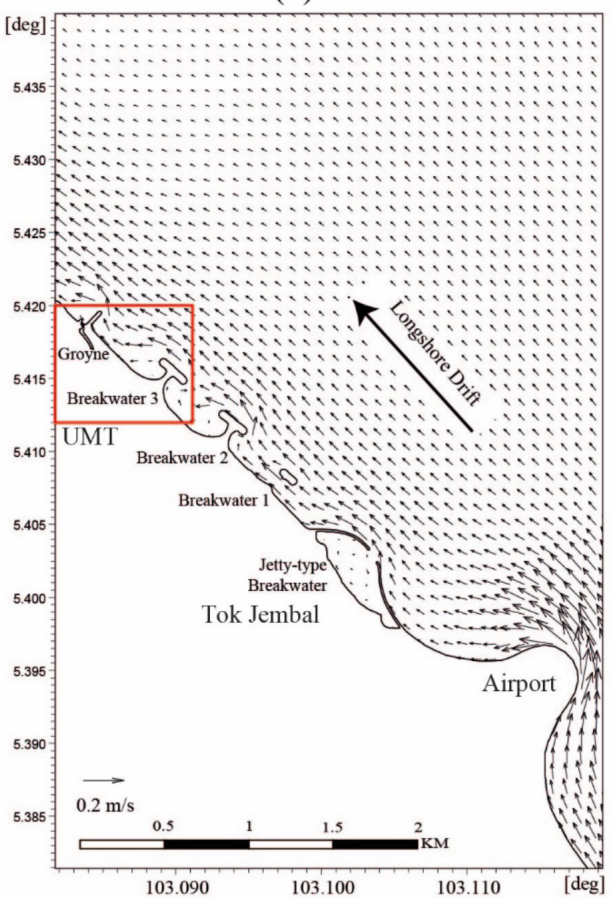

Figure 7: The speed and direction of current from Tok Jembal to Universiti Malaysia Terengganu coastline during the northeast monsoon 2013 and 2017 with the intensity of coastal dynamics highlighted with a red box (beach profile areas) and the longshore drift direction 


\section{Combination of Coastal Defence Structures and Beach Nourishment Effect on Littoral Morphodynamics}

The Department of Irrigation and Drainage proposed to build four series of breakwaters and one groyne under the beach nourishment programme to protect the sand from further erosion (Ariffin et al., 2018b). In Malaysia, coastal erosion not only damages infrastructures such as roads and residential areas, but also disrupts the daily activities of the fishermen community (Muhammad et al., 2016). Therefore, the Public Works Department Malaysia has taken action by building the jettytype breakwater at Tok Jembal for the benefit of the fishermen. Currently, only three breakwaters have been built here. Also, It can be observed that the first breakwater is smaller compared to the other two.

After the beach nourishment programme with the combination of a series of breakwaters and groyne, the study area evolved to be very dynamic, especially its shorelines, beach dune and beach volume, and the net alongshore sediment transport direction. Limitation in budget and tight time-frames in implementing the beach nourishment programme resulted in haphazard sand reclamation unlike in the first plan. However, the main problem in this area originates from a lack of sediment supply attributed to the longshore drift (Figure 7) from the Terengganu River (located south of the airport) and due to the blocking of sediment by the airport runway extension which has a similar design as the groyne (Mohammad Fadhli et al., 2014; Ariffin et al., 2016; 2018b; Ariffin, 2017). India and Taiwan are also facing similar sediment supply in their beach recovery campaign. These areas are totally blocked from the hard structure such as groyne and the erosion is in one area and accretion in another area (Hsu et al., 2007; Vaidya et al., 2015).

This present study also proved that there is high erosional intensity between the groyne and breakwater structure, especially at T3 (red box located at UMT beach in Figure 7). The beach nourishment and coastal defence programme is ongoing and under continuous monitoring by the Department of Irrigation and Drainage. The comprehensive monitoring resulted in the construction of a new riprap in 2017 along the beach susceptible to erosion. Presently, the erosion problem along the Tok Jembal and UMT coasts is still at a controllable phase and the erosion stage is lower than the one reported before the beach nourishment programme. However, intensive precautions need to be taken at the post-groyne area since the dynamic evolution has caused the current to move to the northern area causing catastrophic erosion to the coastline. The importance of coastal mitigation planning should be thoroughly understood and preliminary investigations need to be conducted before any action can be taken. For example, a simulation of the impact of groyne and breakwaters on shorelines can be carried out as a preliminary approach (Vaidya et al., 2015; Prukpitikul et al., 2018).

\section{Conclusion}

Various problems with arising conflicts can be observed due to this combination programme, especially problems that are closely related to the activities of the fishermen community. The problems can be summarised. Firstly, it is the limited sediment supply from the Terengganu River owing to the sediments being blocked by the extension of the airport tarmac. This problem is also responsible for the high current intensity at Tok Jembal coast. Secondly, the construction of a series of ripraps/revetments along the Tok Jembal and UMT beach intensifies erosion rates and thirdly, the insufficient budget and timeframe for the beach nourishment programme. Lastly, the adjustment of beach nourishment programme by replacing the planned structure with the jetty-type breakwater to provide facilities for the fisherman community. The beach nourishment programme needs to be improved as there is a lack of management and planning between most of the stakeholders. It is suggested that all stakeholders should discuss and brainstorm the best and comprehensive coastal mitigation plan to be carried out. A long- 
term mitigation plan can be a more effective approach, especially when it comes to budget. Also, limitation of job scope can be organised. However, primarily, collected data and input of beach morphodynamic influences such as sediment supply and transport, beach processes, physical parameter (wave, current and tide) and anthropogenic activities need to be taken into account for any coastal mitigation plan.

\section{Acknowledgements}

This research was supported by the Ministry of Education Malaysia under the Fundamental Research Grants Scheme (FRGS) [UMT/RMIC/ FRGS/1/2018/59513(1)]. We would like to thank the Laboratory of Physical Oceanography and Geology, UMT for providing the physical data and Mr. Mohd Azam Mat Yaacob for the drone survey. We would like to thank Mr. Mohd Raihan Shah Abdullah who post-edited the English style and grammar.

\section{References}

Aouiche, I., Daoudi, L., Anthony, E. J., Sedrati, M., Ziane, E., Harti, A., \& Dussouillez, P. (2016). Anthropogenic effects on shore face and shoreline changes: Input from a multimethod analysis, Agadir Bay, Morocco. Geomorphology, 254,16-31.

Ariffin, E. H. (2017). Effect of monsoons on beach morphodynamics in the East Coast of Peninsular Malaysia: Examples from Kuala Terengganu coast. Universite de Bretagne-Sud.

Ariffin, E. H., Mathew, M. J., Yaakob, R., Akhir, M. F., Shaari, H., Zulfakar, M. S. Z., Sedrati, M., \& Awang, N. A. (2018a). Beach morphodynamic classification in different monsoon seasons at Terengganu beaches, Malaysia. Journal of Sustainability Science and Management, 13(5), 65-74.

Ariffin, E. H., Sedrati, M., Akhir, M. F., Daud, N. R., Yaacob, R., \& Husain, M. L. (2018b). Beach morphodynamics and evolution of monsoon-dominated coasts in Kuala Terengganu, Malaysia: Perspectives for integrated management. Ocean and Coastal Management, 163, 498-514.

Ariffin, E. H., Sedrati, M., Akhir, M. F., Mohd Norzilah, M. N., Yaacob, R., \& Husain, M. L. (2019). Short-term observations of beach morphodynamics during seasonal monsoons: two examples from Kuala Terengganu coast (Malaysia). Journal of Coastal Conservation, In Press.

Ariffin, E. H., Sedrati, M., Akhir, M. F., Yaacob, R., \& Husain, M. L. (2016). Open sandy beach morphology and morphodynamic as response to seasonal monsoon in Kuala Terengganu, Malaysia. Journal of Coastal Research, 75(Special Issue): 1032-1036.

Ashraful Islam, M., Mitra, D., Dewan, A., \& Akhter, S. H. (2016). Coastal multi-hazard vulnerability assessment along the Ganges deltaic coast of Bangladesh-A geospatial approach. Ocean and Coastal Management, $127,1-15$.

Awang, N. A., Jusoh, W. H. W., \& Hamid, M. R. A. (2014). Coastal erosion at Tanjong Piai, Johor, Malaysia. Journal of Coastal Research, 71(Special Issue): 122-130.

Cohen, O. (2016). Profiler 3.2 XL: Mode d'emploi. New Caledonia.

Daud, N. R., \& Akhir, M. F. M. (2015). Hydrodynamic Modelling of Bidong Island Vicinity Waters. Open Journal of Marine Science, 5(3), 306-323.

DHI. (2011). Mike-Hydrodynamic Module User Guide. Denmark.

ECWMF. (2017). Wind Offshore data. http:// www.ecmwf.int/.

Fatimah, N. H., \& Nuramalina, A. L. (2012). Study on the wave climate variation to the wave power assessment in Merang shoreline of Terengganu area. In Regional Annual Fundamental Science Symposium (RAFSS 2012) (pp. 144-149). Johor Bahru: Universiti Teknologi Malaysia. 
Frihy, O. E., Iskander, M. M., Moniem, A. E., \& Badr, A. (2004). Effects of shoreline and bedrock irregularities on the morphodynamics of the Alexandria coast littoral cell, Egypt. Geo-Marine Letters, 24(4), 195-211.

Hsu, T. W., Lin, T. Y., \& Tseng, I. F. (2007). Human impact on coastal erosion in Taiwan. Journal of Coastal Research, 23(4), 961973.

Kaliraj, S., Chandrasekar, N., \& Magesh, N. S. (2013). Impacts of wave energy and littoral currents on shoreline erosion/ accretion along the south-west coast of Kanyakumari, Tamil Nadu using DSAS and geospatial technology. Environmental Earth Sciences, $71,4523-4542$.

Kok, P. H., Akhir, M. F., \& Tangang, F. T. (2015). Thermal frontal zone along the east coast of Peninsular Malaysia. Continental Shelf Research, 110, 1-15.

Mirzaei, A., Tangang, F., Juneng, L., Mustapha, M. A., Husain, M. L., \& Akhir, M. F. (2013). Wave climate simulation for southern region of the South China Sea. Ocean Dynamics, 63(8), 961-977.

Mohammad Fadhli, A., Subiyanto, Rosnan, Y., Mustafa, M., Aidy, M. M., \& Mohd Lokman, H. (2014). Coastline change in vicinity of runway platform of Sultan Mahmud Airport Kuala Terengganu: Comparative analysis of one-line model versus satellite data. Journal of Applied Sciences, 14(19), 2234-2245.

Mohanty, P. K., Patra, S. K., Bramha, S., Seth, B., Pradhan, U., Behera, B., Mishra, P., \& Panda, U. S. (2012). Impact of groins on beach morphology: A case study near Gopalpur Port, East Coast of India. Journal of Coastal Research, 28(1), 132-142.

Mohd Radzi, A. H., Nor Aslinda, A., \& Kartigeyan, V. (2014). Physical modelling on coastal erosion due to runway extension at Terengganu Airport. Journal of Malaysia Water Research, 5(1), 1-11.
Muehe, D. (2003). Beach morphodynamic research in Brazil: Evolution and applicability. Journal of Coastal Research, 35(Special Issue), 32-42.

Muhammad, M., Idris, K., Ariffin, E. H., Mohamed Shaffril, H. A., Abu Samah, B., \& Suandi, T. (2016). The impact of climate change on small-scale fisherman in Malaysia. The Social Sciences, 11(13), 3352-3356.

Nor Hisham, M. G. (2006). Coastal erosion and reclamation in Malaysia. Aquatic Ecosystem Health \& Management, 9(2), 237-274.

Pandian, P. K., Ramesh, S., Ramana Murthy, M. V, Ramachandran, S., \& Thayumanavan, S. (2004). Shoreline changes and near shore processes along Ennore Coast, East Coast of South India. Journal of Coastal Research, 20(3), 828-845.

Pattiaratchi, C., Olsson, D., Hetzel, Y., \& Lowe, R. (2009). Wave-driven circulation patterns in the lee of groynes. Continental Shelf Research, 29(16), 1961-1974.

Peterson, C. H., \& Bishop, M. J. (2005). Assessing the environmental impacts of beach nourishment. BioScience, 55(10), 887-896.

Prukpitikul, S., Kaewpoo, N., \& Ariffin, E. H. (2018). An evaluation of a new offshore breakwater at Sattahip Port, Thailand. Maritime Technology and Research, 1(1), 15-22.

Saengsupavanich, C. (2013). Detached breakwaters: Communities' preferences for sustainable coastal protection. Journal of Environmental Management, 115, 106-113.

Thieler, E. R., Himmelstoss, E. A., Zichichi, J. L., \& Ergul, A. (2009). Digital Shoreline Analysis System (DSAS) version 4.3-An ArcGIS extension for calculating shoreline change. U.S. Geological Survey Open-File Report 2008-1278.

Türker, U., \& Kabdaşli, M. S. (2007). Verification of sediment transport rate parameter on 
cross-shore sediment transport analysis. Yaacob, R., Shaari, H., Sapon, N., Ahmad, M. F., Ocean Engineering, 34, 1096-1103.

Vaidya, A. M., Kori, S. K., \& Kudale, M. D. (2015). Shoreline response to coastal structures. Aquatic Procedia, 4, 333-340. Arifin, E. H., Zakariya, R., \& Hussain, M. L. (2018). Annual changes of beach profile and near shore sediment distribution off Dungun-Kemaman,Terengganu, Malaysia. Jurnal Teknologi, 80(5), 57-66. 